\section{A first step, but still a long way to go}

\section{San Diego}

THE first US Environmental Protection Agency (EPA) approval of a genetically engineered biological pesticide has heartened the biotechnology industry, but no one expects the decision to herald a flood of approvals for other bioengineered products. The pesticide was produced by a method that sidesteps many of the concerns about genetic engineering that have slowed regulatory acceptance.

In late June, Mycogen Corporation of San Diego received federal approval to begin commercialization of two pesticides, MVP and M-Trak, whose active ingredient is a protein, Bt, produced by the Bacillus thuringiensis bacterium. The successful conclusion to the six-year struggle to get approval brought smiles to many in the biotechnology industry, which has been frustrated by exhaustive regulatory restrictions.

Mycogen's president and chief executive officer, Jerry Caulder, characterized the attitude among his peers as, "Hey, we have one more notch on our gun. We're moving forward. It can be done and someone has done it."

Bt, which has been available as a pesticide for $\mathbf{3 0}$ years, is toxic to a variety of insects but harmless to humans. However, because it degrades within a few days, Bt's effectiveness has been limited. Mycogen improved this benign pesticide by inserting the gene coding for the toxic protein into the bacterium Pseudomonas fluorescens.

Mycogen avoids the questions surrounding environmental release of a genetically modified bacterium by a simple expedient. Following mass fermentation, the Pseudomonas bacteria are killed and treated with a patented process that stabilizes the cell walls and encapsulates the protein crystals. With such a protective shell, the toxins can persist in the field for up to eight days, Mycogen claims. And because no live bacteria are released, the company trimmed the number of years spent seeking federal approval.

Even with killing the bacteria, however, Mycogen was still required by the EPA to field-test its product rather than rely on existing data on Bt. Environmental groups such as the Environmental Defense Fund convinced the federal agency that the protein might be expressed differently in the new bacteria.

Other biotechnology companies are working on different ways to use Bt as a pesticide. Monsanto has created strains of corn that incorporate the $\mathrm{Bt}$ gene into the plant itself. Crop Genetics International is working on a plant 'vaccine' — seeds are inoculated with an bacterium carrying the gene for the Bt protein.

Judy Berlfein

\title{
Staying with California labs
}

\section{Washington}

THE US Department of Energy (DOE) plans to renew its contract with the University of California to manage the Lawrence Berkeley, Lawrence Livermore and Los Alamos national laboratories. The decision, announced by Secretary of Energy James Watkins on 24 July, ends ten months of speculation that the DOE might bring in another contractor, probably from the private sector, to run Livermore and Los Alamos which together are home to most of the US government's nuclear weapons research.

Last week's announcement pleased most researchers at the laboratories, who jealously guard the academic freedom they are allowed within a universitymanaged setting. During the Gulf War, this became a source of friction between the university and DOE, with the department said to be annoyed at the freedom with which Livermore and Los Alamos researchers were allowed to talk to the media.

The decision will be less pleasing to many on the faculties of the various University of California campuses, which have long been uneasy with the system's association with military laboratories.

There was widespread speculation that DOE was not completely satisfied with the California system, either, and that it would open the Livermore and Los Alamos management contracts to competitive bids from a range of organizations. Watkins has expressed a desire to make DOE contractors responsible for any costs incurred because of lax environ- mental standards at the facilities they manage - something the University of California was unwilling to do. And last year came revelations that tens of millions of dollars worth of equipment and some government documents had been found to be missing from Lawrence Livermore (see Nature 346, 97; 1990).

Last September, the university's governing board of regents decided to negotiate to renew the management contracts despite opposition from faculty. But California officials had since made it clear that they are not interested in competing for the contracts.

In agreeing to negotiate on a new contract, the DOE seems to have agreed not to insist that the university system accept financial liability for environmental damage caused by the laboratories.

Some university officials speculate privately that Watkins may have decided to leave the national laboratories with California some time ago, but delayed his announcement to avoid the impression of caving in on the environmental liability issue. Watkins is said to be determined to bring the most polluting among DOE facilities, notably the nuclear weapons production plants, to heel.

The University of California's continued management of Lawrence Berkeley was never in serious doubt, because of the laboratory's intimate association with the university's Berkeley campus. All three laboratories have been run by California since their inception as national facilities between 40 and 50 years ago.

Peter Aldhous

\section{Meagre science budget}

\section{New Delhi}

A crisis in both resources and foreign exchange has forced the two-month-old Indian government to set a meagre 1991-92 budget of 23,900 million rupees ( 570 million) for scientific research and development activities not relating to defence. This is about 2.6 per cent of the country's total budget as it was presented to parliament last week.

Although on paper the research and development budget is nearly 12 per cent more than was spent last year, the increase is apparent rather than real. With the rupee having been devalued since last year by nearly 25 per cent against the pound, the various scientific agencies - which import most of their equipment from abroad - will actually have less to spend.

This year's budget has no allocations for new projects in any of the scientific agencies except the Department of Space. That department plans to set up a third launch pad on the east coast for launching polar satellites and is also hoping to build a new satellite dedicated to beaming educational programmes to classrooms. The government has approved these two schemes, but has made only a token provision of $£ 80,000$ in the budget.

After announcing a new industrial policy that makes it easier for the entry of foreign capital and technologies, the government intends to overhaul science and technology policy as well. Finance Minister Manmohan Singh said that science and technology policy will be reorientated in order to relate it "more intimately to the requirements of our development as well as for better absorption and assimilation of new technologies".

K. S. Jayaraman 